\title{
INEQUALITY, SOCIAL RESPECTABILITY, POLITICAL POWER AND ENVIRONMENTAL DEVASTATION
}

\author{
Jon D. Wisman
}

"An imbalance between rich and poor is the oldest and most fatal ailment of all republics” (Plutarch c. 46 A.D.127 A.D; source unknown).

"Consumer freedom was originally a compensation for the loss of the freedom and autonomy of the producer. Having been evicted from production and communal self-rule, the individual drive to self-assertion found its outlet in the market game. One can suppose that at least in part the continuing popularity of the market game derives from its virtual monopoly as the vehicle of self-construction and individual autonomy. The less freedom exists in the other spheres of social life, the stronger is the popular pressure on the further extension of consumer freedom - whatever its costs” (Bauman 1888: 95).

"the most common and durable source of factions has been the various and unequal distribution of property. Those who hold and those who are without property have ever formed distinct interests in society" (James Madison Federalist \#10, 1787).

ABSTRACT: Although healthy societies may require a degree of material inequality, higher levels of inequality have been linked to negative social consequences ranging from poorer health to lessened democracy. However, the greatest contemporary threat of excessive inequality might be its contribution to increased environmental degradation. Indeed, avoiding devastation of our habitat may be the greatest challenge ever faced by humanity. This article explores the manner in which inequality encourages consumption, by drawing upon Thorstein Veblen's theory of consumer behavior, whereby in societies in which fluid social mobility is believed possible, inequality encourages households to seek social certification and social status through consumption. Rising inequality strengthens the intensity with which households struggle to maintain social respectability through increased consumption. The ideology, institutions, and behavior generated by this focus on consumption reduce the potential for people to achieve certification of value through more environmentally friendly domains such as work and community. This article also addresses the manner in which inequality impedes responses aimed at reducing environmental damage by augmenting the political power of those whose interests would be harmed by environmental measures. Indeed, the wealthy benefit threefold from pollution: Their disproportionate consumption is made less expensive,

\footnotetext{
${ }^{*}$ Professor of Economics at American University, Washington, D.C.
} 
their assets yield higher profits, and they are better able to shield themselves from the negative consequences of environmental destruction.

KEYWORDS: Conspicuous consumption, political power, ideology, work quality, community.

CLASSIFICATION CODES: Q50; P16; B15

It is commonly lamented that households in wealthy societies, and especially American households, have become overly materialistic and that ecological devastation is one of the consequences. But why have they presumably become so materialistic? This article examines the role played by a high degree of inequality, drawing upon Thorstein Veblen's theory of consumer behavior to clarify how inequality encourages households to augment consumption in quest of social certification and self-respect. Rising inequality can be expected to greatly reinforce this dynamic.

Healthy societies may require a degree of material inequality to bring forth socially desirable incentives. However, higher levels of inequality - "socially excessive inequality” -- have been linked not only to lesser economic dynamism (Alesina and Rodrik 1994; Easterly 2002; Persson and Tabellini 1994; Garrison, and Lee 1992), but also to negative social consequences ranging from poorer health to lessened democracy. ${ }^{1}$ But of all negative consequences of excessive inequality, the greatest contemporary threat is arguably its contribution to increased environmental degradation. Indeed, avoiding devastation of our habitat may be the greatest challenge ever faced by humanity. ${ }^{2}$

Research has suggested that for a number of pollution variables, there appears to be an environmental Kuznets curve, whereby an inverted U-shaped curve seems to capture the relationship between rising per capita income and environmental degradation (Grossman and Krueger 1995). Accordingly, in the early stages of economic 
development, raising per capita income worsens pollution, but at a more advanced stage of development, further increases in per capital income correlate with less pollution. Torras and Boyce (1998), however, find that a high degree of inequality partially offsets the later stage decline in ecological devastation. The principal link they find between greater inequality and pollution is that the former creates greater inequality in the distribution of political power such that the wealthy, who most benefit from looser controls on pollution, are better able to block such measures. ${ }^{3}$

Torras and Boyce focus upon how inequality impedes progress in producing a less polluting supply of goods and services. Their focus is on the supply side. However, there is a dynamic on the demand side that has yet to receive notice. Higher inequality also leads to greater environmental degradation by augmenting consumption. This article explores the dynamic by which this occurs by drawing upon Veblen's theory of consumer behavior, whereby in societies in which fluid social mobility is believed possible, inequality encourages households to seek social certification and social status through consumption. ${ }^{4}$ Rising inequality strengthens this dynamic. Further, the ideology, institutions, and behavior generated by this focus on consumption reduce the potential for people to achieve certification of value through more environmentally friendly domains such as work and community. This article also provides further elaboration of the manner in which inequality impedes responses aimed at reducing environmental damage by augmenting the political power of those whose interests would be harmed by environmental measures -- principally the wealthy. The elite benefit more from pollution than the less well off for three reasons: Their disproportionate consumption is less 
expensive, their assets yield higher profits, and they are better able to shield themselves from the harmful consequences of pollution.

Although the analysis developed in this article is intended to apply to all modern societies, it predominantly focuses on the U.S., the wealthiest large economy and the world's greatest polluter in both absolute and per capita terms.

\section{Inequality, the Quest for Social Respectability, and the Environment}

There are three potential reasons why at some more advanced stage of economic development pollution might be expected to decrease with higher per capita income. First, as other needs are better satisfied, a cleaner environment comes to be more greatly valued. Second, new technologies evolve that are less resource intensive. Third, the more intensely polluting sectors such as manufacturing decline relatively as a less polluting service sector expands.

However, as will be demonstrated below, where inequality is great, and especially where it is increasing, status competition augments consumption. Moreover, it does so in luxury goods such as huge homes and powerful automobiles which have considerable environmental impact. Status competition biases consumption toward those goods that are highly polluting in their production and maintenance. It also biases consumption in favor of private goods as opposed to public ones such as quality of the environment.

Social status is critically important to people and thus strongly affects their behavior. As a social being, an individual is motivated, as Karl Polanyi put it "to safeguard his social standing, his social claims, his social assets” (1944: 46). Ultimately underpinning social status or respectability is the need for self-esteem or self-respect, what John Rawls suggested to be "perhaps the most important primary good” such that 
without it nothing else has much value (1971: 440). The human preoccupation with status or relative social position is understandable from an evolutionary perspective. Those with higher status, whatever its source, would possess disproportionate access to resources and members of the opposite sex, thus permitting more and better cared-for progeny. A proclivity for seeking status would thus be naturally selected. Or, as Robert Frank has put it, “falling behind one’s local rivals can be lethal” (2005: 183). The central importance of the respect of others was acknowledged by Veblen: "The usual basis of self-respect is the respect accorded by one's neighbors. Only individuals with an aberrant temperament can in the long run retain their self-esteem in the face of the disesteem of their fellows” (1899: 39).

Historically, humans have sought status or social respectability in varied ways, depending upon prevailing socio-economic conditions. In pre-agricultural societies, high status accrued to the best hunters and gatherers - those who best enabled the group's survival. In predatory cultures, military prowess was favored (the knights in armor). In pre-modern class societies, although class membership rigidly set status between classes, individuals struggled for social respectability and status within their own classes.

Conspicuous consumption would be important within the class that commanded society's surplus, ${ }^{5}$ whereas work and community service would be important within producer classes where, after physical needs were met, little if any surplus remained to fuel conspicuous consumption. However, the rise and maturation of capitalism would eventually "democratize" conspicuous consumption, according it a central role in the struggle for social respectability or status to such an extent that today it poses disastrous consequences for the environment. 
Where it has developed, capitalism has progressively broken down rigid class stratification and created greater potential for vertical social mobility. ${ }^{6}$ This transformation began in the early stages of capitalism as a rising commercial class, a bourgeoisie, began to accumulate wealth and demand social recognition commensurate with its new command over society’s resources. It began to petition for equal status with the aristocracy. ${ }^{7}$ Its success in doing so entailed that the grounding for status slowly shifted from one $=\mathrm{s}$ birth to one $=\mathrm{s}$ achievement. Ascriptive status began to yield to performative status. Through diligent hard work and cleverness, one might rise in status. Vertical mobility became increasingly possible.

Vertical mobility would first become most fully developed in those capitalist countries that were essentially composed of immigrants who had left behind worlds of more rigid status barriers. Thus not surprisingly, considerable vertical mobility was found in countries populated by immigrants such as the U.S., Canada, Australia, and Israel (Tyree et. al. 1979: 415). Nevertheless, the potential for vertical mobility has been expanding in practically all nations.

It should be noted, however, that in terms of people's behavior, more important than the actual degree of vertical mobility is what is believed to be the case. That is, people’s behavior can be expected to correlate more with their belief in the extent of vertical mobility than with what actually exists. Accordingly, their perception of each individual=s potential for changing his or her social status is more a consequence of their understanding, whether true or false, of the degree of Aequality of opportunity@ in their society. 
As Veblen pointed out, in societies in which the potential for vertical mobility is believed to be relatively high, class distinctions become blurred. ${ }^{8}$ Although individuals may have a general sense of where they fall in terms of their society=s distribution of income or wealth, they have little sense of belonging to a class. Indeed, the extent to which this is true in the U.S. is suggested by the fact that most Americans describe themselves as middle class, “a concept that conveys not only one’s economic status but also the sense of being a full participant in a fluid society” (Kuznet, et. al. 2006).

The perceived potential for vertical mobility inculcates a sense that one is responsible for one=s social status. ${ }^{9}$ If one works hard and diligently, one might move up. Therefore, individuals are more prone to internalize responsibility for their successes or failures. This places considerable pressure on people to demonstrate high status. To the extent they succeed in doing so, they appear to possess the virtues of hard work. This places a premium on showing higher status. However, how hard one works is generally not directly observable. What more readily catches attention is how much one can consume, which can stand more or less as a proxy for how hard one has worked. Thus, as people come to believe that they are individually responsible for their own social standing, they feel more strongly compelled to demonstrate status and hence class identity through consumption. ${ }^{10}$ As Veblen noted: “To sustain one’s dignity - and to sustain one’s self-respect - under the eyes of people who are not socially one’s immediate neighbors, it is necessary to display the token of economic worth, which practically coincides pretty closely with economic success” (Veblen, 1919: 393). Further, 
“One’s neighbours ...often are socially not one’s neighbours, or even acquaintances; and still their transient good opinion has a high degree of utility. The only practicable means of impressing one’s pecuniary ability on these unsympathetic observers of one's everyday life is an unremitting demonstration of ability to pay” (1999: 86-87). ${ }^{11}$

If a household consumes at the level of those with higher status, then it might acquire that status and the good reputation that accompanies it. ${ }^{12}$

Where income and wealth inequality are greater, the amount that must be consumed to create the impression of higher status is greater. But inequality would only have this effect where a belief in the potential for vertical mobility is strong. In societies where relatively little potential for vertical mobility is believed to exist, individuals understand their class status as more fixed and known. They possess the status of their parents, which was that of their grandparents and so on. Should their status be low, it is not the result of a personal failing. Moreover, if an individual were to attempt to show greater status through consumption, it would more readily be viewed in a negative light, as "show-off" behavior. Rather than signaling virtue, it would signal a character flaw. Note for instance the negative judgment frequently made of the consumption practices of the self-made wealthy, the so-called nouveau riche.

Veblenian conspicuous consumption manifests itself in two dimensions. Consumption that permits "invidious comparison" is meant to demonstrate one's status to be above those below. "Pecuniary emulation," on the other hand, refers to the practice of imitating the consumption standards of those of higher status with the intent of appearing to also possess that status. Veblen claimed that AWith the exception of the instinct of 
self-preservation, the propensity for emulation is probably the strongest and most alert and persistent of the economic motives proper...[and] the propensity for emulation - for invidious comparison - is of ancient growth and is a pervading trait of human nature” (Veblen 1899: 110; 109). Further, AIn order to gain and to hold the esteem of men it is not sufficient merely to possess wealth or power. The wealth or power must be put in evidence, for esteem is awarded only on evidence@ (Veblen 1899: 36-37).

The argument, then, is that ill-defined class distinctions and a socially generated view of a high degree of vertical mobility suggest that individuals are responsible for their social status. To demonstrate success, households emulate the behavior of those socially above them, thereby generating a high level of conspicuous consumption. This seems to be precisely what Veblen had in mind when he wrote:

“in any community in which class distinctions are somewhat vague, all canons of reputability and decency, and all standards of consumption, are traced back by insensible gradations to the usages and habits of thoughts of the highest social and pecuniary class -- the wealthy leisure class” (1899: 104).

Moreover, Veblen viewed participation in conspicuous consumption as strongly socially compelled "though popular insistence on conformity to the accepted scale of expenditure as a matter of propriety, under pain of disesteem and ostracism.” Thus the consumer’s "motive is a wish to conform to established usage, to avoid unfavourable notice and comment, to live up to the accepted canons of decency...” (1899: 111; 115). So powerful is this motive that "No class of society, not even the most abjectly poor, foregoes all customary conspicuous consumption.... Very much of squalor and discomfort will be endured before the last trinket or the last pretence of pecuniary decency is put away” 
(1899: 85). It is noteworthy that for Veblen, conspicuous consumption is not so much consciously pursued to flash status as undertaken to maintain respectability:

"For the great body of the people in any modern community, the proximate ground of expenditure in excess of what is required for physical comfort is not a conscious effort to excel in the expensiveness of their visible consumption, so much as it is a desire to live up to the conventional standard of decency in the amount and grade of goods consumed” (1899: 102).

More fluid modern social life has eroded the power of traditional or inherited sources of identity in addition to class membership, such as community, ethnicity, religion, and even gender. As noted above, although the residual force of traditional sources of identity is weakest in the new "immigrant” countries such as the U.S, this force is rapidly weakening around the globe. The consequence is that individuals feel ever more responsible for not only their status, but their very self-identity. People experience a greater sense of individuality, so much so that self-identity becomes a project. Consumption, of course, acts as a signaling device for identity, a means to define one's self and to project this definition to others. Maintaining if not improving this identity becomes a never-ending project.

Although inequality is great within countries, it is far greater internationally. The world's wealthiest one percent owns 40 percent of the world's net worth, whereas the bottom 50 percent owns but 1.1 percent (Davies et al 2008). Moreover, this inequality is increasing. International inequality fuels an international “demonstration effect,” whereby the elites in relatively poorer countries emulate the consumption standards of their counterparts in the rich countries. Thus, when the world's most elite raise their 
consumption standards, it puts pressure on the world to follow suit, with negative environmental consequences.

\section{An Intensified Struggle for Status Stability with Rising Inequality}

The greater the degree of inequality, the greater the pressure on households to certify status through consumption. Great inequality means that consumers must stretch further to emulate the consumption standards above them. A further increase in inequality would put more pressure on individuals to consume yet more to attain their status targets.

Over slightly more than three decades from 1973 to 2005, income inequality dramatically increased in the U.S. The poorest 20 percent of Americans saw their share of total income decline from 5.5 percent to 4.0 percent. Over the same period, the second poorest 20 percent saw their share drop from 11.9 to 9.6 percent, the middle 20 percent from 17.5 to 15.3. Meanwhile, the share of the richest 20 percent rose from 41.1 to 48.1 percent. And the richest five percent saw their share climb from 15.5 to 21.1 percent (Table 1.9, Mishel et. al. 2007). Inequality in wealth ownership is yet far greater, ${ }^{13}$ and has also greatly increased over the same period (Wolff 2002).

Keynes claimed in the General Theory that increasing equality would raise consumption, by raising the average marginal propensity to consume (Keynes 1936: 37275). Rising inequality would thus lower consumption because of the lower marginal propensity to consume of the wealthier classes. Veblen's theory of consumer behavior suggests just the opposite consequence - greater inequality increases consumption. The fact that the very wealthy have recently become so much wealthier has meant not only that they have dramatically increased their own conspicuous consumption in their 
competition for the pinnacle of success among themselves, but that because the gap between their consumption level and those below them is so much greater, those below must spend ever more to achieve their status goals, thereby placing increasing demands on the environment.

In a society in which individuals generally feel responsible for their own status and struggle to demonstrate status through consumption, the substantial increase in inequality since the mid-1970s might have been expected to prompt households to respond in one or more of three ways in order to increase consumption: They could have saved less, become more indebted, or increased work hours. Evidence indicates that U.S. households did all three.

Over these decades of rising inequality, the personal saving rate fell from 10.4 percent in $1980-84$, to 7.7 percent in $1985-89$, to 6.5 percent in $1990-94$, to 3.8 percent in 1995-99, to 2.1 percent in 2000-04; and became negative in 2005 and 2006.

As inequality increased, households took on more debt. Average consumer debt in 2003 dollars for Americans over 15 years of age increased from \$712 in 1980 to \$3,261 in 2003 (Adkisson and McFerrin 2005: 447). This increased indebtedness held for households in all income quintiles. ${ }^{14}$ However, the indebtedness of lower and middle income households grew significantly more relative to income than did that of wealthier households (See Table I below). Although there are other hypotheses for why indebtedness of those in the lower part of the income distribution increased (e.g., Weller 2007), the rise in indebtedness for the rich and poor alike fits the hypothesis set forth here, that in a society in which vertical mobility is believed to be highly fluid, increasing 
gaps in income all along the spectrum would stimulate everyone but those at the very top to struggle harder to meet their consumption status targets. ${ }^{15}$

It is noteworthy that increasing income and wealth inequality have occurred even in the highest income decile, with the consequence that even those in this decile have, on average, become increasingly indebted. ${ }^{16}$ The greatest gains in wealth and income went to the super-rich, the top one tenth of one percent (Wolff 2002), dramatically increasing the consumption of extremely expensive goods and services (private jets, mansions, Hirschian positional goods, etc.). These super-rich households are ever in competition with each other for the very pinnacle of status, with the consequence that "In the consumer race the finishing line always moves faster than the fastest of runners” (Bauman 2000: 72). This has put pressure on the lesser rich who also wish to be seen as at the very top. This pressure is reinforced by the advertising and programming that continually keep the consumption standards of the rich and famous on public display (See Schor 1998; Frank 1999). Americans are more targeted than peoples of other cultures by advertising, and this bombardment has become ever more intense. ${ }^{17}$ The role this has played was addressed a half-century ago by John Kenneth Galbraith=s Adependency effect,@ advanced in his The Affluent Society in 1958. It was also the thesis of pop sociologist Vance Packard=s 1957 The Hidden Persuaders. ${ }^{18}$

\section{TABLE I}

Ratio of the Mean Value of Outstanding Debts to Mean Family Income by Percentile

\begin{tabular}{|c|r|r|r|r|r|r|r|}
\hline \multirow{2}{*}{ Income } & \multicolumn{7}{|c|}{ Year } \\
\cline { 2 - 8 } Percentile & 1989 & 1992 & 1995 & 1998 & 2001 & 2004 & 2007 \\
\hline
\end{tabular}




\begin{tabular}{|l|r|r|r|r|r|r|c|}
\hline All Families & $\mathbf{0 . 8 8}$ & $\mathbf{1 . 0 8}$ & $\mathbf{1 . 0 9}$ & $\mathbf{1 . 2 0}$ & $\mathbf{1 . 0 5}$ & $\mathbf{1 . 4 7}$ & $\mathbf{1 . 5 0}$ \\
\hline$<20$ & 0.89 & 0.33 & 1.85 & 1.84 & 1.68 & 2.31 & 2.56 \\
\hline $20-39.9$ & 0.86 & 0.35 & 1.12 & 1.23 & 1.12 & 1.62 & 1.54 \\
\hline $40-59.9$ & 0.85 & 0.42 & 1.03 & 1.19 & 1.18 & 1.61 & 1.72 \\
\hline $60-79.9$ & 0.96 & 0.71 & 1.14 & 1.32 & 1.16 & 1.56 & 1.82 \\
\hline $80-89.9$ & 0.84 & 0.85 & 1.08 & 1.14 & 1.12 & 1.47 & 1.77 \\
\hline $90-100$ & 0.60 & 0.62 & 0.76 & 0.79 & 0.68 & 0.99 & 0.87 \\
\hline
\end{tabular}

\section{Source: Survey of Consumer Finances}

If, as a consequence of rising inequality, individuals must spend ever more to attain their status targets, then it might also be expected that they would increase their work hours to be better able to do so. Indeed, during basically this same period between 1970 and 2002 - work hours per capita rose 20 percent in the U.S. By contrast, in the European Union where income inequality increased far less (excepting the U.K.), work hours fell 12 percent (OECD 2004, Chapter 1). Bowles and Park provide further empirical support "that increased inequality induces people to work longer hours [and] ...the underlying cause is the Veblen effect of the consumption of the rich on the behaviour of those less well off”(2005: F410).

Inequality also appears to influence whether women married to working men take on jobs themselves. A study finds that they are more likely to do so where there is greater inequality in men's incomes (Park 2004). It is also notable that the U.S. is the only wealthy country that does not legally require employers to provide paid leave (Ray and Schmitt 2007: 1). Even when U.S. workers held far more political power than today, they did not strongly pressure government to make leave mandatory. It is conceivable 
that the relatively high conspicuous consumption pressures in the U.S. may help explain why. This is conformable to Veblen's contention that increased productivity would lead to greater conspicuous consumption rather than fewer work hours:

"As increased efficiency makes it possible to procure the means of livelihood with less labour, the energies of the industrious members of the community are bent to the compassing of a higher result in conspicuous expenditure, rather than slackened to a more comfortable pace” (1899: 111). ${ }^{19}$

A "free-to-choose" interpretation would not adequately capture the dynamics of the intensified struggle to maintain status or social respectability as inequality increases. In his last major work, The Revolt of the Elites (1996), Christopher Lasch noted that as economic elites take an ever-greater share of income and wealth, they tend to isolate themselves in social enclaves such as gated communities, exclusive clubs, and private schools. They tend to work in jobs, live in neighborhoods, and move in circles where they literally do not see those struggling to stay on their feet. Because of elites’ disproportionate political power, this withdrawal from wider society and from direct contact with the concerns of other citizens erodes support for public services on which those further down the economic ladder depend—services such as public schools, parks, transportation, public safety, and a clean environment. As Reich has put it, Amembers see no reason why they should pay to support families outside the gates when members are getting everything they need inside...@ (Reich 2001: 199). ${ }^{20}$ The decay of public services encourages those beneath the elites to do what is necessary - reduce saving, become more indebted, or increase work hours - to enable them to send their children to decent schools or to safe recreation centers. ${ }^{21}$ And, of course, as those who can afford to 
consume the private provision of these services opt out of consuming the public ones, political support for, and the quality of, the latter continue to deteriorate. A vicious cycle is set in motion, promising increasingly inferior public goods and ever greater pressure to increase consumption of private goods.

At some point, increased inequality, and especially an increasingly gated-off elite, may impede a society from addressing and solving its collective problems such as inadequate infrastructure or ecological degradation. As Jared Diamond has found in his study of societies that have collapsed due to environmental destruction, Afailures to solve perceived problems because of conflicts of interest between the elite and the masses are much less likely in societies where the elite cannot insulate themselves from the consequences of their actions@ (2005: 431).

\section{Debased Alternatives to Consumption}

A tendency for humans to accumulate material possessions is often presumed to be universal, a direct result of human nature itself. However, a glance at human evolution suggests otherwise. Prior to the adoption of agriculture 10,000 years ago, almost all humans were nomadic, precluding any accumulation of material wealth beyond a few primitive weapons, tools, clothing, and jewelry. Thus, it is only relatively late in the human story that accumulated material wealth even became possible.

Indeed, it is only in the last few centuries that sustainable economic growth has been recognized as possible, generating what might be called a material progress vision. Central to this vision is the presumption that economic growth will make possible the good and just society. Therefore, society should consider economic growth as its highest priority. This has promoted a somewhat exclusive preoccupation with material progress 
as the key to improved human welfare. Largely neglected are such essential components of human welfare as more creative and fulfilling work; greater equality in the distribution of opportunity, income and wealth; richer and more supportive communities; a sustainable environment; and more time for family, friends, and reflection, all of which can be treated as subsidiary issues because maximum material progress is believed to hold the key to a better future. For the sake of maximum economic growth and the greatest potential for augmenting everyone’s consumption, capitalism’s creative destruction must be fully unleashed, even if this results in ever-more intense competition, insecurity, stress, and environmental destruction.

However, a substantial body of work in psychology, especially in what has come to be called "happiness research," finds that above a fairly low threshold, subjective wellbeing does not correlate with higher incomes and thus higher levels of consumption. Although it has been found that average levels of satisfaction are considerably lower in very poor countries than in rich ones, after a certain income level has been attained, further increases in income do not seem related to higher levels of subjective well-being (Diener and Diener 1995; Veenhoven 1993; Easterlin 2001, 2002). In terms of income and consumption, what appears to be important is one's relative position. ${ }^{22}$

Moreover, this preoccupation with material accumulation debases and conceals from view the two interrelated domains of work and community in which fulfillment and self-esteem are more richly nourished. ${ }^{23}$

\section{Work}

Happiness research finds that above a certain material threshold, it is in the realm of work that well-being is most readily achieved. As Robert Lane has put it, "It is in 
work, not in consumption and, as research reports show, not even in leisure, where most people engage in the activities that they find most satisfying, where they learn to cope with their human and natural environments, and where they learn about themselves” (1991: 235).

Having a job - working - is very important for self-identity. A World Values Survey found that "only 22 percent of respondents agreed that a job is just a way of earning money, and 63 percent said that they would enjoy having a paying job even if they did not need the money” (Alesina, Glaeser, and Sacerdote 2002: 239). Diener and Seligman, in reviewing the literature on economic psychology on well-being, find two of the six major factors to be: To live in a democratic and stable society that provides material well-being, and to have rewarding and engaging work and an adequate income $(2004: 25) .^{24}$

Within good workplaces, work provides a ready medium in which self-esteem can flourish. In work we contribute to society=s wealth (as opposed to drawing upon society=s wealth via consumption), and thus we have grounds for a sense that we are participating in achieving society=s well-being. If we are fairly autonomous and possess a degree of control over the work process, we achieve a sense of accomplishment. ${ }^{25}$ We can aid our fellow workers and bask in their appreciation for our assistance and our skills. Self-esteem is highly dependent upon social esteem.

Inequality, however, reduces the potential for work to serve as an adequate medium for achieving fulfillment. Because inequality propels households toward consumption to maintain their social standing, where there is a trade-off between work quality and income, inequality encourages workers to choose the latter. ${ }^{26}$ Work becomes 
more biased toward a means to the end of higher consumption and away from its potential for serving as a vent for self-expression and creativity.

\section{Community}

The debasement of work and the elevation of consumption as the domain in which self-worth and identify are sought works against community. As Bauman puts it, "Producers can fulfill their vocation only collectively; production is a collective endeavour, it presumes the division of tasks, cooperation of actors and coordination of their activities...Consumers are just the opposite. Consumption is a thoroughly individual, solitary and, in the end, lonely activity...” (Bauman 2005: 30). ${ }^{27}$

Inequality reduces the potential for community because, as Irvin reports, it reduces social capital: "Where there is more income inequality, poorer people are more likely to feel out of place participating in community groups, more likely to feel ill at ease and to think that they will make fools of themselves and be looked down upon

(2007: 15) ${ }^{28}$ An important component of social capital is trust. The European and World Values Survey has found that trust is higher in countries with less inequality. The General Social Survey done by the U.S. government has also found that trust is higher in states with less inequality (reported in Wilkinson and Pickett 2009: 53-54).

Wilkinson and Pickett report that "In the USA, trust has fallen from a high of 60 percent in 1960, to a low of less than 40 percent by 2004” (2009: 54). As trust fell, more gated communities sprang up, sales of home security systems grew, and sales of SUVs, -tougher vehicles for the urban jungle - soared. Even the adventuresome youth practice of hitchhiking all but disappeared. 
In their survey of studies on trust, Wilkinson and Pickett find that"With greater inequality, people are less caring of one another, there is less mutuality in relationships, people have to fend for themselves and get what they can - so, inevitably, there is less trust.... High levels of trust mean that people feel secure, they have less to worry about, they see others as co-operative rather than competitive” (2009: 56; 57). Planet Ark Environmental Foundation has found that more equal societies tend to have greater social cohesiveness and public spiritedness, resulting in greater recycling of waste materials (Planet Ark 2004).

Also working against community is the fact that greater inequality generates more criminal activity. Kelly finds that inequality has Aa strong and robust impact on violent crime, with an elasticity above $0.5 "$ (2000: 530). This research is supported by that of Fajnzylber et. al. who find in a study of 39 countries between 1965 and 1995 that violent crime rates and inequality were positively correlated Awithin countries and, particularly, between countries, and this correlation reflects causation from inequality to crime rates, even after controlling for other crime determinants@ (2002: 1).

A belief in the potential for fluid mobility came with the breaking of inherited class power and promised more equality of opportunity. However, where inequality is great, an extreme adherence to this belief can work against a sense of community. This appears to be the case in the U.S. with its strong belief in the possibility of vertical mobility and high degree of inequality. Individuals not only readily take credit for their economic successes, but also readily view the less fortunate as responsible for their economic failures. Alesina, Glaeser, and Sacerdote report that the World Values Survey found that 71 percent of Americans versus 40 percent of Europeans believe that the poor 
could work their way out of poverty. “...54 percent of Europeans believe that the poor are unlucky, whereas only 30 percent of Americans share that belief." And "Sixty percent of American respondents, but only 26 percent of Europeans say that the poor are lazy” (2001: 237; 242; 243). These differences may also help explain Americans' stronger embrace of laissez-faire political ideology (see also, Lipset 1998). Alesina and La Ferrara find that in the U.S., those individuals who believe they will experience future income growth more readily oppose measures that would redistribute income in favor of the less well-off (2001). Other evidence also suggests that to a greater extent Americans hold individuals responsible for their own fates. For instance, Alesina, Glaeser, and Sacerdote report that they "find an extremely strong relationship in the United States between supporting capital punishment and opposing welfare” (2001: 242).

In devaluing the potential for work and community to provide social certification and personal fulfillment, inequality feeds a material progress vision, the view that evergreater material abundance is the key to happiness.

\section{Inequality and Political Opposition to Ecological Safeguards}

The elite benefit more from pollution than the less well off for three reasons: First, much pollution is the consequence of externalities, of some costs of production not being included in the cost of output. This means that the social costs of production exceed market prices, and thus because the rich consume more per capita than do the less well off, they proportionately benefit more from pollution. ${ }^{29}$ Wilkinson and Pickett suggest, for instance, that "The carbon emissions caused by the consumption of a rich person may be ten times as high as the consumption of a poorer person in the same society” (2009: 218). Viewed internationally, the U.S. produces 24.0 tons of carbon per 
person annually, whereas India produces 1.6 tons (Wilkinson and Pickett 2009: 220). The world's richest decile consumes 59 percent of the world's private consumption, leaving only 41 percent for the remaining 90 percent. The lowest decile consumes onehalf percent of world private consumption (World Bank 2008). ${ }^{30}$

Second, the elite gain more from pollution because they hold greater ownership claim to industries that have higher profits because they pass costs off onto the environment. ${ }^{31}$ In 2007, for instance, the wealthiest one percent of Americans owned 49.3 percent of stocks and mutual funds, the richest 10 percent, 89.4 percent. The remaining 90 percent owned only 10.6 percent (Wolff 2010: Table 9: 52).

The third reason that the elite benefit more from pollution is that their wealth and privilege enable them to better shield themselves from the harmful consequences of pollution (Princen 2002), whereas the least privileged suffer most (Boyce 2007; Bullard 2000; Szasz and Meuser 1997). ${ }^{32}$ Thus, for instance, numerous studies have found that the poorer a neighborhood, the greater the likelihood that its air is polluted. In the U.S., African-American populations are disproportionately found near waste sites (Szasz and Meuser 1997: 101; 109).

The wealthy elite that most benefits from pollution spontaneously gravitate toward political and economic doctrines that are supportive of their self-interests. And their more sophisticated educations and better access to information mean that they are less likely to be fooled as to just what these self-interests are. They do not, of course, opportunistically pursue their own interests any more than do other folks. But their privileged status and greater resources mean they can do it better. And, like folks generally, they do not see themselves as consciously doing so. All people want to be 
highly principled, to see themselves as supporting the causes of the good and just society. They come to believe quite sincerely that the economic and political doctrines they support are best for the country, for its freedoms, its fundamental values, and in fact, best for the future well-being of all humanity.

But the result of their disproportionate political power, as Former Secretary of Labor during the Clinton Administration, Robert B. Reich, argues, is that “A major reason why government is failing to provide leadership is because...big corporations [disproportionately owned by the very elite, as noted above] have become so effective in recent years at preventing government from doing much about the environment or any other issue that may require corporations to change in ways they'd prefer not to" (Reich 2008: 169)..$^{33}$

Reich provides numerous examples: “The U.S. government has not increased automobile fuel economy standards in several decades, or made any major move to increase gas taxes to better reflect the true social cost of oil” (Reich 2008: 194). And "When oil prices soared in 2005 and early 2006, oil companies reaped extraordinary profits while millions of Americans had to pay more to fuel their cars and heat their homes. This prompted calls for Congress to enact a 'windfall profits tax' on the oil companies, but not even a debate took place. Instead, Congress simply scolded oil company executives and publicly berated the companies” (Reich 2008: 196).

The reach of corporate power exerts itself in crafting society's ideology. As an example, ExxonMobil contributed \$2.9 million in 2005 to 39 groups that could generate doubts as to whether global warming is occurring or if so, whether it is a consequence of human activity (Timmons 2006: A1). This same company, along with other energy 
companies, gave Stanford University a grant for \$225 million for a ten-year “Global Climate and Energy Project” (Washburn 2006: 13).

Moreover, those who would win from measures to protect the environment are the many, each gaining very little from such actions, ${ }^{34}$ whereas those who would lose are few with considerable interest in the outcome. As Olsen (1965) noted, it is far easier to organize a smaller group with a common interest in rent seeking, and even more so when they have resources to lobby and make political campaign contributions. ${ }^{35}$

Kevin Phillips suggests that this is already the case. He argues that American Apolitics is increasingly dominated by people in the upper-income brackets@ (2002: 15). For political scientist Robert Hunter Wade, this domination is by extremely few Americans: "The people who make the economic and political decisions that matter are concentrated in the top 1 percent of the U.S. household income distribution” (2004: 71).

\section{FINAL REFLECTIONS}

Humanity faces its greatest challenge ever. Mounting evidence suggests we are participating in the rapid destruction of our habitat. Our predicament is ironic because it results from our extraordinary success in the primordial struggle with nature to overcome dire material privation. There are many ways to gauge our species’ success. Population has exploded from 1.6 billion in 1900 to 6.8 billion today, and is expected to peak at about 9.3 billion by 2050. Another measure is the rising number of humans who come of age without fear of starvation and who live in unprecedented abundance. But increasing population and greater affluence are placing unsustainable burdens on our environment. Moreover, inequality-driven conspicuous consumption, which Veblen correctly viewed as "indefinitely expansible" (1899: 111), hastens humanity toward catastrophe. 
The world's poor urgently need the fruits of material progress. However, the material progress vision and the social institutions that support it and are legitimated by it have locked the materially privileged into a never-ending pursuit of ever-greater material output that not only appears to yield no further increases in happiness, but threatens humanity's very future. This vision has nourished a view that inequality is not important. As Martin Feldstein puts it: "I want to stress that there is nothing wrong with an increase in well-being of the wealthy or with an increase in inequality that results from a rise in high incomes” (1999: 35-36). ${ }^{36}$ And, if greater inequality augments growth potential, then that is fine. Many (most?) mainstream economists have embraced this view. ${ }^{37}$

However, as this article has demonstrated, inequality greatly impairs society's ability to address its greatest challenge by increasing consumption and putting greater political power in the hands of those who most benefit from polluting activities. New less-polluting technologies and heightened environmental awareness promise progress in limiting devastation. But in the long term, humans must re-craft institutions and our view of ourselves so as to redirect our energies spent in seeking social certification of our value toward non-material objectives such as more rewarding work and more cohesive communities. Our best hope in the short run is to reduce inequality and implement more stringent measures to protect the environment. But so long as such measures are opposed by an elite that holds disproportionate political power and disproportionately benefits from policies that are enabling further devastation of the environment, such hope will be in vain.

\section{REFERENCES}

Adkisson, Richard V., and Randy McFerrin. 2005. "Living Large: Evolving Consumer Credit Institutions and Privately Induced Transfer Payments." Journal of Economic Issues, v39 (2):447-54. 
Alesina, Alberto, and Eliana La Ferrara. 2001. "Preferences for Redistribution in the Land of Opportunities.” Working Paper 8267. Cambridge, Mass.: National Bureau of Economic Research (May).

Alesina, Alberto, Ed Glaeser, and Bruce Sacerdote. 2002. "Why Doesn’t the United States Have a European-Style Welfare State?” Brookings Papers on Economic Activity, 2, 187-277.

Alesina, Alberto, Rafael Di Tella and Robert MacCulloch. 2004. AInequality and Happiness: Are Europeans and Americans Different? Journal of Public Economics, 88 (9), 2009-42

American Political Science Association. 2004. "American Democracy in an Age of Rising Inequality” 2004. Task Force on Inequality and American Democacy.

Aristotle. 1962. Politics in The Politics of Aristotle. Ernest Barker, ed. New York: Oxford University Press.

Bauman, Zygmunt. 1988. Freedom. Minneapolis: University of Minnesota Press.

Bauman, Zygmunt. 2000. Liquid Modernity. Malden, MA: Blackwell.

Bauman, Zygmunt. 2005. Work, Cosumerism and the New Poor. $2^{\text {nd }}$ Ed. New York: Open University Press.

Bellah, Robert N., Richard Madsen, William M. Sullivan, Ann Swindler, and Steven M. Tipton (1985) Habits of the Heart: Individualism and Commitment in American Life. New York: Perennial Library.

Blethen, Frank A. 2004. AStop the Media Mergers,@ The Washington Post, September 19: B7.

Bostany, Nora. 2006. APress Freedom Erodes in U.S., Report Says,@ The Washington Post, October 24: A15.

Boyce, James K. 2007. “Inequality and Environmental Protection,” in Inequality, Collective Action, and Environmental Sustainability, Jean-Marie Baland, Pranab Bardhan, and Samuel Bowles, eds. Princeton: Princeton University Press: 314-48.

Boyce, James K., Andrew R. Klemer, Paul H. Templet, and Cleve E. Willis. 1999. "Power Distribution, The Environment, and Public Health: A State-level Analysis," Ecological Economics, 29: 127-40.

Bowles, Samuel and Yongjin Park. 2005. "Emulation, Inequality, and Work Hours: Was Thorstein Veblen Right?” The Economic Journal, 115, November, F397-412. 
Bullard, Robert D. and Glenn S. Johnson. 2000. "Environmental Justice: Grassroots Activism and Its Impact on Public Policy Decision Making,” Journal of Social Issues, 56 (3): 555-78.

James B. Davies, Susanna Sandström, Anthony Shorrocks, and Edward N. Wolff. 2008. “The World Distribution of Household Wealth,” World Institute for Development Economics Research, United Nations University, Working Paper 2008/03, February.

Dawson, Michael. 2005. The Consumer Trap: Big Business Marketing in American Life Urbana, IL.: University of Illinois Press.

DeNavas-Walt, Carmen, Bernadette D. Proctor, and Cheryl Hill Lee. 2006. U.S. Census Bureau, Current Population Reports, P60-231: Income, Poverty, ahd Health Insurance Coverage in the United States: 2005. Washington, DC: U.S. Government Printing Office.

Diamond, Jared. 2005. Collapse: How Societies Choose to Fail or Succeed. New York: Viking.

Diener, Ed, and Carol Diener (1995) AFactors Predicting the Subjective Well-Being of Nations,” Journal of Personality and Social Psychology, 59, 851-64.

Diener, Ed, and Martin Seligman. 2004. "Beyond Money. Toward an Economy of Well-Being,” Psychological Science in the Public Interest, 5 (1): 1-31.

Easterlin, Richard. 2001. “Income and Happiness: Toward a Unified Theory,” Economic Journal, 111 (473): 465-84.

Easterlin, Richard. 2002. Happiness in Economics. Cheltenham: Edward Elgar.

de Tocqueville, Alexis. 2003. Democracy in America. London: Penguin.

Duesenberry, James S. 1967. Income, Saving, and the Theory of Consumer Behavior. Cambridge, MA: Harvard University Press.

Fajnzylber, Pablo, Daniel Lederman and Norman , Loayza. 2002. AInequality and Violent Crime,@ Journal of Law and Economics, 45, April: 1-45.

Feldstein, Martin. 1999. “Reducing Poerty Not ilnequality,” Public Interest, Fall: 33-41.

Frank, Robert H. 2000. “Does Growing Inequality Harm the Middle Class?” Eastern Economic Journal, 26 (3): 253-64.

Frank, Robert H. (1999) Luxury Fever: Why Money Fails to Satisfy in an Era of Excess. The Free Press. 
Frank, Robert H. 2005. "Positional Externalities Cause Large and Preventable Welfare Losses,” American Economic Review, 95 (2): 137-41.

Frank, Robert. 2007. Falling Behind: How Rising Inequality Harms the Middle Class. Berkeley, CA: University of California Press.

Galbraith, John Kenneth. 1958. The Affluent Society. Boton, Houghton Mifflin.

Galbraith, John Kenneth. 1973. APower and the Useful Economist,@ American

Economic Review, Vol. 63 (1), March: 1-11.

Gilbert, Dennis. 2011. The American Class Structure in an Age of Growing Inequality.

$8^{\text {th }}$ Ed. Los Angeles: Sage.

Grossman, G. M., and A. B. Krueger. 1995. "Economic Growth and the Environment," Quarterly Journal of Economics, 110: 353-77.

Hirsch, Fred. 1976. Social Limits to Growth. Cambridge: Harvard University Press.

Irvin, George. 2007. “Growing Inequality in the Neo-liberal Heartland,” Post-Autishtic Economics Review, 43: 1-23.

Jargowsky, Paul. 1997. Poverty and Place: Ghettos, Barrios, and the American City. New York: Russell Sage.

Kelly, Morgan. 2000. AInequality and Crime,@ The Review of Economics and Statistics, 84 (2), November: 530-39.

Kennickell, Arthus B. 2006. "Currents and Undercurrents: Changes in the Distribution of Wealth, 1989-2004,” Federal Reserve Board Survey of Consumer Finances Working Paper. www.federalreserve.gov/pubs/oss/oss/method.html.

Keynes, John Maynard (1932) Essays in Persuasion.” New York: Harcourt, Brace and Co.

Keynes, John Maynard. 1936. The General Theory of Employment, Interest, and Money. New York: Harcourt, Brace \& World, 1965.

Kinzie, Susan. 2008. “U.S. Lags in Providing College Access, Study Finds,” The Washington Post, December 3, A6.

Kusnet, David, Lawrence Mishel, and Ruy Teixeira. 2006. Talking Past Each Other: What Everyday Americans Really Think (and Elites Don't Get) about the Economy. Washington, D.C.: Economic Policy Institute.

Lane, Robert E. 1991. The Market Experience. New York: Cambridge University Press.

Lasch, Christopher. 1995. The Revolt of the Elites : and the Betrayal of Democracy. New York : W.W. Norton. 
Low, Setha M. 2003. Life, Security, and the Pursuit of Hapiness in Fortress America. New York: Routledge.

Lucas, Robert E., Jr. “The Industrial Revolution: Past and Future,” 2003 Annual Report Essay, The Federal Reserve Bank of Minneapolis, $\underline{\text { : http }}$ //www.minneapolisfed.org/publications_papers/pub_display.cfm?id=3333

OECD: Organization for Economic Cooperation and Development. 2004. OECD Employment Outlook 2004. Paris: OECD.

Olson, Mansur. 1965. The Logic of Collective Action. Cambridge, MA: Harvard University Press.

Packard, Vance. 1959. The status seekers; an exploration of class behavior in America and the hidden barriers that affect you, your community, your future. New York: D. McKay Co.

Park, Yongjin. 2004. Veblen Effect on Labor Supply: Male Earnings Inequality Increases Women's Labor Force Participation. New London, CT: Department of Economics, Connecticut College.

Pew Research Center. 2008). http://people-press.org/report/395/economic-discontentdeepens-as-inflation-concerns-rise, February 14.

(Pew Research Center 2008. http://people-press.org/report/?pageid=1282, March 27.

Phillips, Kevin (interview). 2002. AToo Much Wealth, Too Little Democracy,@ Challenge, September/October, 6-20.

Planet Ark. 2004. The Recycling Olympic Report. Sydney: Planet Ark Environmental Foundation.

Polanyi, Karl. 1944. The Great Transformation. Boston: Beacon Press, 1957. Princen, Thomas. 2002. "The Shading and Distancing of Commerce: When Internalization Is Not Enough,” in Confronting Consumption, Princen et al, eds. Cambridge, MA: MIT Press, Chapter 5, pp. ????

Rawls, John (1971) A Theory of Justice. Cambridge: Harvard University Press.

Reich, Robert B. 2001. The Future of Success. New York: Alfred A. Knopf, see especially 194-213.

Reich, Robert B. 2008. Supercapitalism: The Transformation of Business, Democracy, and Everyday Life, New York: Alfred A. Knopf.

Russell, Bertrand. 1961. The Basic Writings of Bertrand Russell. R.E. Egner and L. Dennon, eds. New York: Simon and Schuster. 
Schor, Juliet B. 1991. The Overworked American: The Unexpected Decline of Leisure. New York: Basic Books.

Schor, Juliet B. 1998. The Overspent American: Upscaling, Downshifting, and the New Consumer. New York: Basic Books.

Scott, Robert H. III. 2007. “Credit Card Use and Abuse: A Veblenian Analysis,” Journal of Economic Issues, XLI (2), June: 567-74.

Shipman, Alan. 2004. "Lauding the Leisure Class: Symbolic Content and Conspicuous Consumption,” Review of Social Economy, 62 (3): 277-89.

Sidanius, Jim, and Shana Levin, Christopher M. Federico and Felicia Pratto. 2001. ALegitimizing Ideologies: The Social Dominance Approach,@ The Psychology of Legitimacy: Emerging Perspectives on Ideology, Justice, and Intergroup Relations, John T. Jost and Brenda Major, eds. Cambridge: Cambridge University Press.

Smith, Adam. 1978. Lectures on Jurisprudence. Oxford: Oxford University Press.

Smith, Adam. 1776. An Inquiry into the Nature and Causes of the Wealth of Nations. Vol. I. Indianapolis: Liberty Classics, 1981.

Solnick, Sara. J. and David. Hemenway, 1998. “Is More Always Better? A Survey on Positional Concerns,” Journal of Economic Behavior and Organization, 37: 373-83.

Szasz, Andrew, and Michael Meuser. 1997. "Environmental Inequalities: Literature Review and Proposals for New Directions in Research and Theory," Current Sociology, 45 (3), July: 99-120.

Timmons, Heather. 2006. "Exxon Accused of Deception on Climate Change, Royal Society in U.K. Complain to Firm,” International Herald Tribune, September 22: A1.

Torras, Mariano, and James K. Boyce. 1998. "Income, Inequality, and Pollution: A Reassessment of the Environmental Kuznets Curve,” Ecological Economics, 25: 147-60.

Trigg, Andrew B. 2001. “Veblen, Bourdieu, and Conspicuous Consumption,” Journal of Economic Issues, XXXV (1), March: 99-115.

Twitchell, James B. 2002. Living it Up: America's Love Affair with Luxury New York: Simon and Schuster.

Tyree, Andrea and Moshe Semyonov and Robert W. Hodge. 1979. AGaps and Glissandos: Inequality, Economic Development, and Social Mobility in 24 Countries,@ American Sociological Review, 44, June: 410-24.

Uslaner, E. 2002. The Moral Foundations of Trust. Cambridge: Cambridge University Press. 
Varoufakis, Yanis. 2002. AAgainst Equality,@ Science and Society, 66 (4), Winter, 44872.

Veblen, Thorstein. 1899. The Theory of the Leisure Class. New York: The Modern Library, 1934.

Veblen, Thorstein. 1919. "Some Neglected Points in The Theory of Socialism," in The Place of Science in Modern Civilization. New York: B.W. Huebsch, 387-408.

Veenhoven, Ruut (1993) Happines in Nations: Subjective Appreciation of Life in 56 Nations. Rotterdam: Erasmus University.

Wade, Robert Hunter (interview with). 2004. AThe American Empire,@ Challenge, January-February, 64-77

Wallich, Henry C. 1972. “Zero Growth,” Newsweek, 24, January.

Washburn, Jennifer. 2006. “The Best Money Can Buy,” Los Angeles Times, July 21: 13.

Wilkinson, Richard, and Kate Pickett. 2009. The Spirit Level: Why More Equal Societies Almost Always Do Better. London: Allen Lane.

Wolff, E. N. 2010. "Recent trends in household wealth in the United States: Rising debt and the middle-class squeeze - an update to 2007," Working Paper No. 589. Annandaleon-Hudson, NY: The Levy Economics Institute of Bard College.

World Bank Development Indicators. 2008. Http://www.globalissues.org/print/issue/235.

\section{NOTES}

\footnotetext{
${ }^{1}$ Indeed, Wilkinson and Pickett (2009) have found that more unequal societies score lower on practically every measure of quality of life. Even within the United States, states with higher levels of inequality typically have more severe social problems.

${ }^{2}$ It has be been suggested that our earth has entered a new geological era, the anthropocene. This name captures the pervasive human impact on the whole earth, from the deepest oceans to the edge of space. If this continuing impact were to end the planet's ability to support human life, it would be ecocide.

${ }^{3}$ Grossman and Krueger had pointed out "that there was no reason to believe that the process [inflection in the environmental Kuznet curve] is an automatic one.” Instead, it results from "an induced policy response... driven by citizen demand" (1995: 371-72). But such a policy response might be weakened if the winners from not addressing environmental devastation hold more political power than the losers.

${ }^{4}$ Although Veblen's theory of consumer behavior has been the target of numerous attacks, Andrew Trigg argues convincingly that they "misrepresent Veblen's original conception of conspicuous consumption and take it out of context in relation to his overall framework" (2001: 100).
} 


\begin{abstract}
${ }^{5}$ Indeed, so important was conspicuous consumption for the European aristocracy in the late middle ages that, according to Adam Smith, it ultimately cost them their status: “...for the gratification of the most childish, the meanest and the most sordid of all vanities, they gradually bartered their whole power and authority (1776: 389).
\end{abstract}

${ }^{6}$ In pre-capitalist highly organized societies, status was ascriptive, ascribed by birth, by one=s parents= status. Practically no vertical mobility was possible. Everyone had their Aborn-to@ status. As Aristotle put it, AFrom the hour of their birth, some are marked out for subjection, some for command@ (Politics 1962, Book I). This was their identity. Not only were there practically no avenues for raising one=s status, but any attempt to do so was discouraged, if not punished.

${ }^{7}$ Understandably, the aristocracy would struggle to block this quest, even in the domain of conspicuous consumption. Sumptuary laws B especially laws proscribing lower classes from wearing the garments of the classes above them B proliferated in the late Middle Ages in Europe, and even into colonial America. There were even special courts enforcing these dress codes.

8 Veblen put this as follows:

"In modern civilized communities the lines of demarcation between social classes have grown vague and transient, and wherever this happens the norm of reputability imposed by the upper class extends its coercive influence with but slight hindrance down through the social structure to the lowest strata. The result is that the members of each stratum accept as their ideal of decency the scheme of life in vogue in the next higher stratum, and bend their energies to live up to that ideal. On pain of forfeiting their good name and their self-respect in case of failure, they must conform to the accepted code, at least in appearance.... No class of society, not even the most abjectly poor, foregoes all customary conspicuous consumption” (Veblen 1899: 84, 85).

${ }^{9}$ By contrast, in traditional societies in which status was ascribed, high status individuals felt their status was their right. Indeed, they generally understood themselves to be in fact superior, whereas those below felt themselves to be in fact inferior. Note the extreme case of India=s Auntouchables,@ who, until fairly recently in their history, generally believed that their grim existence at the bottom of the social structure was due to poor karma in an earlier incarnation, and thus justly deserved.

${ }^{10}$ Beyond Veblen, Duesenberry also identified a relationship between belief in social mobility and consumption: “...recognition of upward mobility as a social goal converts the drive for self-esteem into a desire for high social status [which] requires the maintenance of a high consumption standard” (1949: 31). He did not, however, develop this relationship in the direction of the argument set forth here.

11 There are, of course, other, aesthetically more sophisticated means by which those successful in earning a good deal of money can demonstrate their virtue and status. But, as Veblen noted, the "cultivation of the aesthetic faculty requires time and application, and the demands made upon the gentleman in this direction therefore tend to change his life of leisure into a more or less arduous application to the business of learning how to live a life of ostensible leisure in a becoming way" (1899: 75-75). The consequence, as Alan Shipman notes, is that "Those who have got rich quick have an understandably low tolerance for the time and tuition needed to gain cultural accomplishment. So they aim to let depth of pocket prevail over depth of discernment, and shift the battlegound from unearned income to unashamed expenditure” (2004: 279).

${ }^{12}$ It should be noted, however, that despite the decline in the Protestant ethic, status today is understood to be far more the consequence of hard work than was the case at the time Veblen was writing. Writing at the end of the $19^{\text {th }}$ century, Veblen viewed people as struggling to exhibit leisure status, that is, to be above work. He noted, for instance, that "wealth acquired passively by transmission from ancestors or other antecedents presently becomes even more honorific than wealth acquired by the possessor's own effort.” And, "The leisure class stands at the head of the social structure in point of reputability; and its manner of life and its standards of worth therefore afford the norm of reputability for the community" (1899: 29; 84). The reason for this, he claimed, is that "During the predatory culture labour comes to be associated in 
men's habits of thought with weakness and subjection to a master. It is therefore a mark of inferiority, and therefore comes to be accounted unworthy of man in his best estate. By virtue of this tradition labour is felt to be debasing, and this tradition has never died out” (1899: 36).

In wealthy countries today, and even to some degree in less wealthy countries, these attitudes toward work and leisure are no longer prevalent. Instead, everyone feels compelled to work. Even the very rich work. It is through work that social certification occurs. Some of this change has taken place over the past 40 years. In the 1960s, people revered the leisured so-called Ajet-setters.@ Today, they would be more readily looked upon as flawed, or even debauched.

${ }^{13}$ The Gini coefficient for household net worth in 2004 was 0.81 (Kennickell 2006: 10), whereas the Gini coefficient for household money income in 2005 was 0.47 (DeNavas-Walt et al. 2006: 7).

${ }^{14}$ Supporting this relationship between inequality and indebtedness, Frank (2007) reports that in those parts of the U.S. where inequality had most risen over a ten-year period, bankruptcy rates also rose the most. More striking, when the economy was booming with very low unemployment in the late 1990s, personal bankruptcy was four times greater than in the 1970s before the explosion in inequality.

15 Increased availability of credit instruments such as home equity loans and credit cards greatly facilitated this emulative consumption. See Scott 2007.

${ }^{16}$ Houses and cars are principal symbols of status, and in the years prior to the crisis of 2008 there was an explosion in the consumption of so-called McMansions and extremely expensive cars. Not surprisingly from the vantage point of the thesis set forth in this article, a February 2008 Pew survey found that "the proportion of wealthy Americans who say they are very satisfied with their housing and cars, in particular, has declined considerably since 2001” (Pew Research Center 2008).

${ }^{17}$ The mainstream of the discipline has been reluctant to bring into their analysis any effect of advertising on consumer preferences. Indeed, some have gone so far as to deny any such effect (e.g., Stigler and Becker 1977).

${ }^{18}$ For more recent analyses of the effect of advertising on consumption, see Dawson 2005, Twitchell 2002.

${ }^{19}$ Keynes expressed a somewhat similar view in delineating two classes of human needs, "those needs which are absolute in the sense that we feel them whatever the situation of our fellow humans may be, and those which are relative in the sense that we feel them only if their satisfaction lifts us above, makes us feel superior to, our fellows” (1932: 365). However, his view that less inequality would increase consumption does not concord with this distinction between absolute and relative needs.

Writing almost two decades ago, Juliet Schor noted that

"Since 1948...the level of productivity of the U.S. worker has more than doubled. In other words, we could now produce our 1948 standard of living ...in less than half the time...We actually could have chosen the four-hour day...In 1990 the average American owns and consumes more than twice as much as he or she did in 1948, but also has less free time” (1991: 2).

${ }^{20}$ Reich goes on to argue that communities are increasingly becoming commodities, sought out and purchased like other commodities, Amarketed, evaluated, and purchased like any other@ (2001: 198). This, of course, intensifies the segregation of the population according to income and privilege.

${ }^{21}$ Frank has also pointed to this dynamic:

"Increased spending at the top of the income distribution has not only imposed psychological costs on families in the middle, it has also raised the cost of achieving many basic goals. Few middleincome parents, for example, would be comfortable knowing that their children were attending below-average schools. Yet the amount that any given family must spend to avoid that outcome depends strongly on the amounts that others spend.... [Moreover], people cannot send their children to a public school of even average quality if they buy a home in a school district in which house prices are well below average” (2000: 258). 
${ }^{22}$ The importance of relative income standing has been confirmed in a study by Solnick and Hemenway (1998) that finds that when presented with the question of whether they would prefer to live less-well-off in a rich society or near the top in a poorer society, fifty percent claimed they would give up half their real income to live in a society where they were betteroff than most others.

${ }^{23}$ Although perhaps contradicted by their behavior, in their extensive interviews of Americans, Bellah et. al. found them in agreement that

"...two of the most basic components of a good life are success in one's work and the joy that comes from serving one's community. And they would also tend to agree that the two are so closely intertwined that a person cannot usually have the one without having the other" (1985: 196).

${ }^{24}$ The other four are: to have supportive friends and family, to be reasonably healthy and have treatment available in case of health problems, to have important goals related to one's values, and to have a philosophy or religion that provides guidance, purpose, and meaning to one's life.

${ }^{25}$ Lane maintains that AThere is evidence that exercise of discretion on the job, which is not so much a right as a requirement of complex tasks, has more substantial effect on self-esteem than any exercise of familiar political rights has ever had@ (Lane 1991: 198).

${ }^{26}$ The labor market reinforces this tendency. As Lane points out, AIn the labor market where workers are free to choose, there is poor information on quality of work life, the default values of money are strong, family benefits flow from money but not for intrinsic satisfaction@ (1991: 406).

27 "The activity of consumption ...[renders] all efforts of bonding impotent in overcoming the endemic loneliness of the consuming act. Consumers are alone even when they act together” (Bauman 2005: 31).

${ }^{28}$ Jargowsky provides further evidence supporting Lasch=s thesis that Americans are becoming increasingly segregated by income and privilege. He also finds that because of disparities in income between racial and ethnic peoples, this segregation is working against racial and ethnic harmony (1997).

${ }^{29}$ In the U.S., 38.5 percent of total consumer spending is done by the wealthiest 20 percent of the population (Consumer Expenditure Survey 2008). In 2007, the wealthiest 10 percent held 45.9 percent of total home equity and 25.5 percent of the value of vehicles (Gilbert 2011: 91).

${ }^{30}$ A striking gauge of the extent of differences in purchasing power is that according to UNICEF, the income of the world's richest 225 individuals is as much as that of the poorest one billion people, or onesixth of humanity (cited in Varoufakis 2002: 448).

31 They have also benefited from an explosion in salaries and bonuses. In 1978, CEOs of the largest U.S. companies earned 35 times as much as the average worker. In 2010, they earn 300 times more.

${ }^{32}$ As Boyce has put it, "The Global environment is our common home, but not everyone lives in the same room (2007: 314).

${ }^{33}$ An international study has found that, controlling for per capita income, a more equal distribution of political power, as gauged by degree of political democracy, civil rights, and literacy, correlates with environmental quality (Boyce 2006). In another study of the 50 American states, a more equal distribution of political power correlated with stronger environmental policies (Boyce et al. 1999).

${ }^{34}$ Also, "Citizens with lower or moderate incomes speak with a whisper that is lost on the ears of inattentive governmental officials, while the advantaged roar with a clarity and consistency that policymakers readily hear and routinely follow” (American Political Science Association 2004: 1). 
${ }^{35}$ Further, the Abehavioral asymmetry thesis [of social dominance theory] suggests that dominants will behave in a more group-interested fashion than subordinates due to the consensual endorsement of hierarchy-enhancing legitimizing ideologies. Moreover, under certain circumstances, not only will subordinates not behave in as group-interested a fashion as dominants, but they will actually work against their own group=s interests@ (Sidanius, et. al. 2001: 318). Their relatively lesser access to information concerning just what their own self interest is makes this all the more likely.

${ }^{36}$ Wallich noted that "Growth is a substitute for equality of income. So long as there is growth there is hope, and that makes large income differentials tolerable" (Wallich 1972; cited in (Wilkinson and Pickett 2009: 221).

37 The1995 recipient of the Nobel Memorial Prize in Economic Sciences even went so far as to declare that any concern with inequality is bad for the science of economics: "Of the tendencies that are harmful to sound economics, the most seductive, and in my opinion the most poisonous, is to focus on questions of distribution” (Lucas: 2004). 